\title{
Early Emergence and Development of Protophones in the First Year of Life
}

\author{
Hyunjoo Yoo ${ }^{\mathrm{a}}$, D. Kimbrough Oller ${ }^{\mathrm{b}, \mathrm{c}}$, Seunghee $\mathrm{Ha}^{\mathrm{d}}$ \\ ${ }^{a}$ Department of Communicative Disorders, University of Alabama, Tuscaloosa, USA \\ ${ }^{b}$ School of Communication Sciences and Disorders, University of Memphis, TN, USA \\ 'Konrad Lorenz Institute for Evolution and Cognition Research, Klosterneuburg, Austria \\ ${ }^{d}$ Division of Speech Pathology and Audiology, Audiology and Speech Pathology Research Institute, Hallym University, Chuncheon, Korea
}

Correspondence: Seunghee $\mathrm{Ha}, \mathrm{PhD}$ Division of Speech Pathology and Audiology, Audiology and Speech Pathology Research Institute, Hallym University, 1 Hallymdaehak-gil, Chuncheon 24252, Korea

Tel: +82-33-248-2215

Fax: +82-33-256-3420

E-mail: shha@hallym.ac.kr

Received: January 5, 2021

Revised: January 30, 2021

Accepted: January 30, 2021

\begin{abstract}
Objectives: Speech-like vocalizations (i.e., protophones) are precursors to speech. Infants produce various types of protophones (e.g., squeals, vocants and growls), practicing phonatory control before mastering articulation. In order to better understand infant vocal development, it is important to systematically investigate production of protophones from the beginning of life. The purposes of this study were (1) to investigate early emergence of protophones, (2) to measure volubility for both cry and protophones across the first year of life, (3) to explore effects of age and types of vocalizations, and (4) to examine protophone volubility in circumstances where the caregiver did not speak to or in the vicinity of the infant. Methods: 16 typically developing Korean-learning infants participated in all-day LENA (Language Environment Analysis) recordings in their homes as part of a longitudinal study. We categorized infant protophones as either squeals, vocants, growls, or cries based on auditory/acoustic criteria. We calculated average numbers of each type of vocalization and average vocalizations per minute. Generalized Estimating Equations (GEE), $t$-test, and ANOVA were conducted to address the research questions. Results: Results showed that even in the first month of life, infants do not merely cry, but instead predominantly produce protophones. Infants also endogenously produced protophones from the beginning of life in the absence of caregiver language input. Conclusion: This study suggests that even in the first month protophones begin to occur, and may form a foundation upon which vocal category development and vocal interaction can proceed rapidly.
\end{abstract}

Keywords: Speech-like vocalizations, LENA, Newborns, Infants, Cry 원시발성(protophones) 또는 언어이전기 발성(prelinguistic vocalizations)은 영아가 의미 있는 첫 낱말을 시작하기 전에 산출하 는 성인의 말소리와 비슷한 발성(speech-like vocalizations)들을 통 칭하는 말로서 영유아의 말-언어발달에 매우 중요하다(Koopmansvan Beinum \& van der Stelt, 1986; Oller, 2000; Stark, 1980). 이러한 원시발성에는 생후 6-7개월에 산출되기 시작하는 음절성 옹알이 (canonical babbling)를 비롯하여 준공명음(quasivowels), 구잉 (gooing), 완전공명음(full resonant nuclei), 고성(squeals), 탁성 (growls), 유사 모음(vocant), 투레질(raspberries), 경계선 옹알이 (marginal babbling) 등이 포함된다. 영아는 처음 발성 단계(phona- tion stage)를 시작으로 원시조음(primitive articulation), 확장(expansion), 음절성 옹알이 발달 단계를 거치며 앞에서 열거된 다양 한 원시발성 유형을 산출한다(Oller, 2000).

원시발성은 다음과 같은 특성으로 인해 말-언어발달에 기초가 된다. 첫째, 원시발성은 성인 언어의 중요한 특성이기도 한 기능적 유연성(functional flexibility)을 보인다. Oller 등(2013)은 영아의 자 발적인 원시발성(spontaneous vocalizations)이 특정한 감정(예: 부 정적, 중립, 긍정적)에 밀접하게 관련하여 산출되는 것이 아니라 오 히려 영아가 자유자재로 같은 종류의 발성(예: 고성)을 다양한 감정 과 함께 표현한다는 것을 보고하였다. 예를 들어, 성인 언어의 경우 
“날씨가 좋네,"라는 같은 문장이 다양한 감정 혹은 상황에서 쓰일 수 있으며 이는 모든 언어의 중요한 특성인 기능적 유연성을 보여준 다. 이와 비슷하게, 영아의 경우에도 고성을 다양한 감정과 함께 유 연하게 사용하여, 대부분의 경우( $90 \%$ 이상) 부정적 감정과 연관되 는 울음, 긍정적 감정과 연관되는 웃음과는 분명히 구별되는 기능 적인 특성을 보였다. 비록 관찰되는 발성의 형태가 제한적이고 원시 적일 수 있으나 성인의 구어에서 보이는 특성, 즉 같은 종류의 발성 을 다양한 감정 및 상황에서 유연하게 사용한다는 점에서 원시발 성이 언어발달과 밀접한 관련이 있음을 증명하고 있다. 반면에 울 음의 경우에는 이러한 기능적 유연성이 관찰되지 않았고 대다수의 경우 특정한 한 가지의 감정인 부정적 감정과 연관되어 산출되는 것으로 보고되었다. 종합하면 원시발성의 경우는 추후 말-언어발 달에 중요한 전조(precursor) 역할을 하는 반면, 울음은 영아의 부 정적인 현재 기분이나 상태를 반영하는 것으로(fixed signal) 두 소 리가 서로 분명히 구분되는 발달적 기능이 있다.

둘째, 생후 초기부터 원시발성이 산출되는 것은 양육자와의 원 시대화(protoconversation)를 위해서도 중요하다. 원시대화가 영아 의 말-언어발달을 촉진한다는 것은 잘 알려진 사실이다 (Papoušek, 1995; Trevarthen, 1977; Tronick, Als, \& Brazelton, 1980). 영아와 양육자의 주고받기(turn-taking) 연구에서는 원시발성을 통해 양 육자와 영아가 원시대화를 한다고 일관되게 보고하고 있다(Fogel,

Toda, \& Kawai, 1988; Kärtner, Keller, \& Yovsi, 2010; Keller, Kärtner, Borke, Yovsi, \& Kleis, 2005). 영아가 원시발성을 산출하고 그것 이 원시대화의 재료로 쓰인다는 점에서 양육자가 원시발성을 어떻 게 인지하고 있는지도 매우 중요하다. Yoo, Bowman과 Oller (2018) 는 양육자가 영아의 원시발성을 어떠한 교육 없이도 생후 직후부터 직관적으로 울음 소리와 구분하여 시간적, 형태적으로 울음에 대 한 반응과는 다른 반응을 한다는 것을 보고하였다. 연구에 따르면 양육자는 영아의 원시발성에 대해서는 생후 첫 달부터 말 주고받기 의 형태로 영아의 원시발성에 뒤이어 반응한 반면, 울음에 대해서 는 영아의 울음을 그치게 하려는 시도로 중복되게 반응하였다. 양 육자가 직관적으로 기능이 다른 두 소리에 다르게 반응하였는다는 것은 양육자의 직관적 육아(intuitive parenting) 본능에 대해서 간 접적으로 보여주는 것이며, 이러한 양육자의 반응은 말-언어발달 에 영향을 줄수 있다(Papoušek \& Papoušek, 2002).

또한 생후 직후부터 많은 산출량을 보이는 원시발성이 영아의 현 재 건강 상태를 보여주는 신호(fitness signal)로 작용하여 언어의 진화와 관련되어 있다는 주장이 있다. 이는 말-언어발달을 다루는 본 연구의 영역을 벗어나는 주제이므로 자세히 다루지는 않지만 보 다 자세한 정보를 원하는 독자는 다음의 참고 문헌을 살펴볼 수 있
다(Locke, 2006, 2017; Locke \& Bogin, 2006; Oller, Griebel, \& Warlaumont, 2016).

이처럼 원시발성은 성인 언어의 특성을 공유하고 있으며, 말-언 어발달에 중요한 기초가 된다. 원시발성, 그 중에서도 음절성 옹알 이는 영아의 초기 단어와음절 형태, 음소 배열 및 발성의 길이 등에 서 연속성을 보인다(Ferguson, Macken, \& Nelson, 1983; Locke, 1989; Vihman, Macken, Miller, Simmons, \& Miller, 1985; Whitehurst, Smith, Fischel, Arnold, \& Lonigan, 1991). 초기 단어와의 연 속성 뿐만 아니라 음절성 옹알이는 언어발달 지연의 참고지표로도 사용될 수 있다(Belardi et al., 2017; Lang et al., 2019; Nyman \& Lohmander, 2018; Oller, Eilers, Neal, \& Cobo-Lewis, 1998; Törölä, Lehtihalmes, Heikkinen, Olsén, \& Yliherva, 2012). 예를 들어, 정상 발 달과 청각장애 영아의 음절성 옹알이 산출 시기를 연구한 Oller와 Eilers (1988)의 연구에 따르면 연구에 참여한 정상 청력 영아들은 생후 6 개월에서 10 개월 사이에 모두 음절성 옹알이를 산출하기 시 작하였으나, 청각장애 영아들 중에서는 아무도 10 개월 전에 음절 성 옹알이를 산출하지 않았다. 자폐(Autism Spectrum Disorders, $\mathrm{ASD}$ ) 아동의 경우 음절성 옹알이의 산출 비율이 일반 아동에 비해 현저히 낮게 보고되었다(Oller et al., 2010; Patten et al., 2014). 이러 한 언어발달 측면의 중요성으로 인하여 언어발달 연구자뿐 아니라 최근에는 언어의 진화, 기계 학습과 같은 다양한 영역에서 음절성 옹알이에 관한 관심이 증가하고 있다(Locke, 2008; Moulin-Frier, Nguyen, \& Oudeyer, 2014; Warlaumont \& Finnegan, 2016). 따라 서 영유아의 발성에 관한 연구가 많이 부족한 현재 상황에도 불구 하고 음절성 옹알이에 관한 연구는 비교적 꾸준히 진행되고 있다.

그러나 음절성 옹알이 이전에 나타나는 전 음절성 발성(precanonical vocalizations)에 관한 연구는 발성 발달의 기초가 된다는 중요성에도 불구하고 국내외를 막론하고 연구가 매우 부족한 실정 이다. 연구가 부족한 여러가지 이유 중의 하나는 많은 연구자들이 신생아 시기에는 영아가 울음을 통해 주로 의사소통을 하는 것으 로 가정하여 왔기 때문이다(Lester \& Boukydis, 1992; Wasz-Höckert, Lind, Vuorenkoski, Partanen, \& Valanne, 1968; Zeifman, 2001). 또한 영유아의 발성/음성 발달 단계를 소개하는 경우 보통 원시발 성의 발생 시기를 2-3개월 이후로 나타내고 있으며, 생후 직후인 신 생아 시기에는 울음이 주로 관찰되는 것으로 표기하고 있다(Hoff, 2009). 일부 학자들의 경우 언어발달과 울음의 관련성을 주장하는 경우도 있다(Wermke, Leising, \& Stellzig-Eisenhauer, 2007). 이처럼 신생아 시기의 발성은 연구가 많이 이루어지지 않았을 뿐 아니라 일 부 출판된 연구의 경우에도 울음에만 초점이 맞춰서 있는 경우가 많았다(for review see Wasz-Höckert, Michelsson, \& Lind 1985). 
그러나 최근 들어 몇몇 영어권 연구자들이 울음이 신생아 시기 의 주요 의사소통 도구라는 기존의 가정이나 추측을 반박하는 경 험적인 연구 결과를 보고하고 있다(Nathani, Ertmer, \& Stark, 2006; Oller et al., 2014, 2019). 원시발성과 울음, 두 종류의 발성을 구별할 수 있는 청지각적인 기준을 이용하여 산출의 비율을 월령에 따라 비 교한 연구에 따르면 영아의 출생 직후인 신생아 시기에도 원시발성 이 뚜렷하게 관찰되며 원시발성의 발생 비율이 울음보다 현저하게 높다. 더욱이 만삭아로 태어난 영아뿐 아니라 조산으로 신생아 집중 치료실에서 보호를 받는 영아의 경우에도 원시발성의 주요 유형인 고성, 탁성과 유사 모음을 산출하는 것으로 보고되어(Oller et al., 2019) 전 음절성 발성에 관한 연구의 필요성이 더욱 높아지고 있다.

국외의 상황과 비슷하게 전 음절성 발성에 관한 국내 연구도 매 우 부족한 실정이다. 최근에는 영아의 발성 발달에 관한 국내 연구 가 증가하고 있으나 영아의 발성 발달 메커니즘에 관해서는 아직 시작 단계라고 할 수 있다. 영유아 시기의 발성/음성 발달을 연구한 몇몇 논문들의 경우에도 분절음적인 특징에 더욱 중점을 두는 경 우가 많고(Kim, Yoon, Park, Park, \& Lee, 2017; Jang \& Ha, 2019, 2020), 음절 발달과 구분되며 음절 발달에 선행되는 발성 조절 능력 (phonatory control)을 연구한 논문의 수는 더욱 적다. Pae와 Ko (2010)의 연구가 발성 조절 능력을 연구한 소수의 논문 중 하나인데 신생아 시기인 생후 1 개월부터 18 개월까지 영유아의 음성 특징을 보고하였다. 이 논문은 국내에서 연구가 매우 제한적인 신생아 시 기부터 시작하는 발성 발달에 관한 음성 특징을 자세히 보고하고 있어 발달 단계의 추이를 살펴보는 데 유용하다. 다만 원시발성의 음성적 특징 보고를 주요 목적으로 하여 단계별로 새로운 유형의 출현에 관해 주로 보고하였으며 각 유형의 양적인 변화에 대한 정 보에는 제한이 있다. Ha, Seol과 Pae (2014)는 5-20개월 영유아의 초 기 발성 발달을 스탁 초기 발성 발달 평가-개정판(Stark Assessment of Early Vocal Development- Revised, SAEVD-R; Nathani et al., 2006)의 기준을 근거로 하여 보고하였다. 23 개의 항목에 해당 하는 다양한 발성 유형에 근거하여 영유아의 발성 발달 추이를 보 여준다는 점이 유용하지만 연구에서도 밝히고 있듯이 피험자의 월 령이 5 개월부터 시작되어 생후 직후부터 시작되는 발성 발달을 분 석하지 못한 것은 제한점이라고 할 수 있다. 또한 SAEVD-R의 경우 고성을 3단계(생후 3-8개월)에 처음 출현하는 것으로 제안하고 있 으며, 탁성은 유형에 포함되지 않았다. 더불어 발성과 음절 발달 유 형이 구분되지 않고 모두 포함되어 발성 조절 능력에 초점을 둔 본 연구의 기준과는 차이가 있다.

영유아의 말-언어발달에 있어 중요한 발달 과제 중의 하나는 진 성(modal voice)의 메커니즘을 습득하는 것이다(Buder, Chorna,
Oller, \& Robinson, 2008). 진성은 일상적인 대화 대부분에서 성인 이 주로 사용하는 음역(register)의 하나로서(Hollien, Girard, \& Coleman, 1977) 음절성 옹알이를 습득하는 데 있어서도 중요한 발 달 조건 중의 하나이다(Oller, 2000). 영아가 음절성 옹알이를 거쳐 의미 있는 첫 낱말을 산출하고 단계적인 말-언어발달의 시기를 거 치기 위해서는 가장 기초가 되는 발성 조절 단계를 거치며 기본적 인 발성 유형의 소리를 산출, 탐색, 연습하는 단계가 선행되어야 한 다(Oller, 2000; Oller et al., 2016). 발성 조절 능력의 발달에 있어 가 장 주요한 원시발성의 유형은 진성을 바탕으로 한 유사 모음, 대체 로 높은 음도에서 산출되는 고성, 비교적 낮은 음도에서 거친 음성 적 특성을 함께 보이는 탁성을 들 수 있다. 고성은 영아의 습관적 음 도(habitual pitch)를 벗어나는 높은 음도에서 산출되는 발성으로 가성(falsetto or loft)으로 산출되기도 하고 가성과 진성 사이를 오 가며 산출되기도 한다(Buder, Jarmulowicz, \& Oller, 2013; Oller 2000). 국내에서는 Pae와 Ko (2010)가 고성으로 명명하여 본 연구 에서도 고성을 사용하였다. 탁성은 보통 습관적 음도 보다 낮는 음 도에서 산출되며 종종 습관적 음도내에서 산출되지만 거친 소리 (harshness)를 포함하기도 하고, 음성 프라이(vocal fry or pulse)를 포함하기도 한다(Buder et al., 2013; Oller 2000). Pae와 Ko (2010)에 서는 웅얼거림으로 명명하였으나, 본 연구에서는 고성의 대칭어로 서 낮은 음도에서 나는 소리의 특성을 나타낼 수 있고 탁한 목소리 라는 뜻도 포함되어 있는 탁성(濁聲)이라는 용어를 사용하였다 (National Institute of Korean Language, 2008). 이 소리들은 영아 가 발성 조절 능력 중 음도(pitch)를 습득하는 데 주로 탐색하는 소 리들로서 원시발성 중 주된 산출 비율을 보이는 소리이기도 하다. 해부학적 관점의 성도 발달 및 말 발달 단계를 고려해도 영아가 다 양한 발성을 듣고 스스로 연습하고 점차 각각의 발성 유형을 조절 할수 있는 능력을 기른다는 것은 이후의 음절 및 조음 발달에도 매 우 밀접하게 연관되는 선행적 단계이다(Stark, Bernstein, \& Demorest, 1993). Moulin-Frier 등(2014)은 기계 학습을 이용하여 컴퓨터 모델이 가장 간단한 단계에서 자발적으로 탐색하고 연습하면서 (self-organization) 점점 복잡하고 어려운 단계의 발성으로 발전한 다는 것을 보고하며, 기본적 단계인 발성 발달의 중요성에 대해 언 급하였다. Brainard와 Doupe (2000) 역시 청각적 피드백 모델(auditory feedback model)의 원리를 근거로 발성 발달을 위해서는 자 신의 소리를 듣고 판별할 수 있는 과정이 필수적이라고 하였다. 이 처럼 원시발성 중에서도 가장 기초가 되는 전 음절성 발성의 발성/ 음성 발달을 연구하는 것은 이후의 음절성 발성 및 말-언어발달을 이해하는데 필수적이다.

말-언어발달에 중요한 발성/음성 발달의 추이를 살펴보기 위하 
여 본 연구에서는 영아의 생후 첫 달인 0 개월부터 13 개월까지의 발 성 자료를 이용하여 다음의 연구문제를 조사하였다.

1. 신생아 시기의 원시발성과 울음의 비율은 어떠한가?

2. 원시발성과 울음의 산출 비율이 월령별로 차이가 있는가?

3. 원시발성 유형에 따라 산출 비율에 변화가 있는가?

4. 성인의 언어 자극이 없는 상황에서 영아가 자발적으로 원시발 성을 산출하는가?

\section{연구방법}

\section{연구대상}

본 연구는 한국어권 영아 16 명(남: 7명 여: 9명)을 대상으로 하였 다. 양육자와의 면담을 통하여 영아의 발달 상황 및 영아에 대한 기 본 정보를 수집하였다. 연구에 참여한 모든 영아는 신생아 청력선 별검사를 통과하였고, 임신 및 출산 전후에 발달적으로 특이한 사 항이 없는 것으로 보고된 정상 발달 영아이다. 본 연구는 한국어권 영유아의 말-언어발달 종단 연구를 위해 수집된 녹음 자료 중 일부 인 0-13개월의 발성 발달 자료를 사용하였다.

\section{자료수집}

양육자가 종단 연구에 참여하기로 결정하면 연구자(언어병리학 전공 대학원생)가 아동의 집에 직접 방문하여 녹음 자료 수집에 필 요한 정보를 제공하였다. 먼저 연구자는 양육자와의 인터뷰를 통해 아동의 신체 및 인지 발달을 포함한 전반적인 발달 상황과 영아 및 양육자의 기본 정보를 수집하였다. 인터뷰 후에는 연구자가 아동의 발성 녹음을 위한 안내를 제공하였다. 아동의 발성은 최대 16 시간 까지 녹음이 가능한 Language ENvironment Analysis (LENA) 녹 음기를 이용하여 수집하여 대표성이 높은 영아의 발성을 근거로 본 연구를 진행하였다(Fagan \& Doveikis, 2017; Xu et al., 2008). 양 육자는 LENA 녹음기 사용법을 숙지한 후 연구자가 방문한 날을 기준으로 하여 일주일 이내에 일상적인 상황에서 하루 12 시간 이 상 아동의 발성 및 환경음을 연속적으로 녹음하였다.

종단 연구에 참여한 아동들은 생후 0-6개월 사이에 처음 연구에 참여하기 시작하였고, 처음 녹음한 날을 기준으로 아동이 생후 18 -20개월이 될 때까지 3 개월마다 아동의 발성 발달 녹음 자료를 수집하였다(Table 1). 각 아동별로 처음 연구에 참여하기 시작한 월 령이 다르므로 처음 시작 월령에 따라 3 개월 마다 수집한 발달 녹 음 자료의 월령을 Table 1 에 제시하였다. 예를 들어, 1 번 영아의 경 우 생후 0 개월에 연구에 참여하기 시작하였고, 이후 $3,6,9$ 개월에 발성 녹음 자료를 수집하였다. 이러한 방법으로 0-2개월 집단의 경
Table 1. Available recordings from each infant at each month

\begin{tabular}{|c|c|c|c|c|c|c|c|}
\hline & \multirow[b]{2}{*}{ Gender } & \multicolumn{6}{|c|}{ Age groups (months) } \\
\hline & & $\begin{array}{c}\text { A } \\
(0-2)\end{array}$ & $\begin{array}{c}B \\
\text { (3-4) }\end{array}$ & $\begin{array}{c}C \\
(5-6)\end{array}$ & $\begin{array}{c}D \\
(7-8)\end{array}$ & $\begin{array}{c}E \\
(9-10)\end{array}$ & $\begin{array}{c}F \\
(11-13)\end{array}$ \\
\hline INF01 & $\mathrm{F}$ & 0 & 3 & 6 & & 9 & \\
\hline INF02 & $\mathrm{F}$ & 1 & 4 & & 7 & 10 & \\
\hline INF03 & $\mathrm{F}$ & 1 & 4 & & 7 & 10 & 13 \\
\hline INFO4 & $\mathrm{F}$ & 1 & 4 & & 7 & 10 & 13 \\
\hline INF05 & $M$ & 2 & & 5 & 8 & & 11 \\
\hline INF06 & $M$ & 2 & & 5 & 8 & & 11 \\
\hline INF07 & M & 2 & & 5 & 8 & & 11 \\
\hline INF08 & $\mathrm{F}$ & 2 & & 5 & 8 & & 11 \\
\hline INF09 & $\mathrm{F}$ & & 3 & 6 & & 9 & 12 \\
\hline INF10 & $\mathrm{F}$ & & 3 & 6 & & 9 & 12 \\
\hline INF11 & M & & 3 & 6 & & 9 & 12 \\
\hline INF12 & $M$ & & 4 & & 7 & 10 & \\
\hline INF13 & $M$ & & 4 & & 7 & 10 & 13 \\
\hline INF14 & $\mathrm{F}$ & & 4 & & 7 & 10 & 13 \\
\hline INF15 & $\mathrm{F}$ & & & 5 & 8 & & 11 \\
\hline INF16 & M & & & 5 & 8 & & 11 \\
\hline Total recordings & & 8 & 10 & 10 & 12 & 10 & 13 \\
\hline
\end{tabular}

우 총 8 개의 발성 녹음 자료가 본 연구에 포함되었다. 또한 아동의 표현 어휘 수와 목록 수집을 위하여 아동이 생후 18-20개월이 되면 양육자에게 한국판 맥아더-베이츠 의사소통발달 평가 기록지(Korean MacArthur-Bates Communicative Development Inventories, K M-B CDI; Pae \& Kwak, 2011)를 실시하였다. 본 연구와 연구를 위 한 영유아의 발성 발달 녹음 자료 수집은 한림대학교 생명윤리위 원회의 승인을 받아 진행되었다(IRB 승인번호: HIRB-2016-078-3CCR).

\section{자료분석}

본 연구에서는 선행연구에서 제시된 발성 분류의 청지각적 기준 을 근거로 영아의 원시발성과 울음의 산출 비율을 분석하였다(Oller, 2000; Oller et al., 2013, 2019; Buder et al., 2008, 2013). 다양한 원시 발성의 유형 중 성대의 조절 연습 및 발성 놀이(vocal play)와 연관 된 발성 유형 세 가지 즉, 고성, 중성 및 탁성으로 영아의 원시발성을 분류하였다. 선행연구에서 “vocant”는 준공명음(quasivowel)과 완 전공명음(full vowel)을 통칭하는 용어로 사용하였다(Buder et al., 2013). 그러나 동시에 음도를 기준으로 발성 유형을 분류할 때는 중 간 음역이나 진성 발성을 나타내는 용어로서, 분절음적 특성이 아 닌(자/모음의 산출여부와 무관하게) 발성 유형을 분류할 때 고성, 탁성과 함께 사용하였다(Buder et al., 2008; Oller et al., 2013, 2019). 따라서 이를 유사 모음으로 번역하여 사용할 경우 본 연구의 목적 
과 달리 모음의 산출량을 조사한 것으로 혼동할 여지가 있어, 고성 과 탁성의 중간 음역을 뜻하는 중성을 사용하였다.

종합하면 본 연구에서 사용한 분류 방법, 즉 발성/음성 유형은 성도의 형태 및 분절음적 요소(자/모음)의 포함 여부와 무관하게 산출된 원시발성의 음도 변화 및 성대 진동 유형(vocal regime)을 기준으로 하여 원시발성을 분류하는 방법이다. 예를 들어, 영아가 /아/를 산출하였을 때 원시발성의 음도 변화를 기준으로 하여 중 성, 고성, 탁성으로 분류한다. 또한 울음의 경우에는 크게 분류하여 전형적 울음(wail)과 훌쩍임(whimper)으로 나눌 수 있는데(Oller et al., 2019; Yoo et al., 2018; Yoo, Buder, Bowman, Bidelman, \& Oller, 2019), 본 연구에서는 이 유형을 따로 구분하지 않고 모두 울 음으로 분류하였다. 전형적 울음은 대체로 발성의 길이가 길고, 소 리가 크며, 음도가 높은 특징이 있다. 훌쩍임은 성대에서 나는 흐느 낌과 같은 소리(glottal burst)가 특징적인 울음으로 기침과 비슷한 소리로 대체로 짧은 소리가 연속적으로 산출되며 전형적 울음과 비교할 때 소리가 현저히 작다. 원시발성과 울음 모두 호흡 단위 (breath group, Lynch, Oller, Steffens, \& Buder, 1995)를 근거로 발 성 유형을 분류하고 발성 수를 계산하였다. 발성 유형 분류 시 생리 적 발성(vegetative sounds)과 몸의 움직임으로 인해 부수적으로 발 생되는 그렁거림(grunt)은 분류에서 제외하였다.

중성은 일상 생활에서 성인들이 가장 일반적으로 사용하는 발 성의 유형으로 말-언어발달 과정에 있는 영아도 이러한 발성을 산 출한다. 발성 유형 중 가장 기본이 되는 중요한 소리로서 대체로 완 전한 성대의 접촉과 진동을 통해 발생하는 음성이라 할 수 있다 (Titze, 2008). Figure $1 \mathrm{~A}$ 는 0 개월 영아의 발성 녹음 자료에서 추출 된 중성의 예로서 음향학적 특성을 스펙트로그램을 통해 볼 수 있 다. 이 소리는 대체로 영아의 일반적인 음역대에서 산출되며 일정하 고 균일한 고조파음(harmonics)이 특징적이다.

고성은 중성보다 보통 2-3배의 높은 음역대에서 산출된다. 가성 으로 산출되거나 진성과 가성을 오가며 산출되기도 한다. 보통 맑 고 음도가 높은 소리가 특징적이지만 간혹 거칠고 높은 소리가 산 출되기도 한다. Figure $1 \mathrm{~B}$ 는 중성과 같은 영아에서 추출된 고성의 예로 고조파음의 간격이 넓어 중성보다 높은 음도의 특성을 보여 준다.

탁성은 고성과 반대로 중성보다 대체로 낮은 음도에서 산출된다. 종종 음도는 중성의 음역대와 비슷하지만 거칠고 탁한 소리가 함께 산출되기도 한다. 거칠고 탁한 소리의 경우 음성 체계 분석의 기준 에 따르면 저조파 성분(subharmonic)이나 이중 발성 성분(biphonation)이 포함되어 있는 경우가 많다. 음성 프라이가 포함될 때도 탁성으로 분류한다. Figure $1 \mathrm{C}$ 는 저조파 성분을 보여준다.

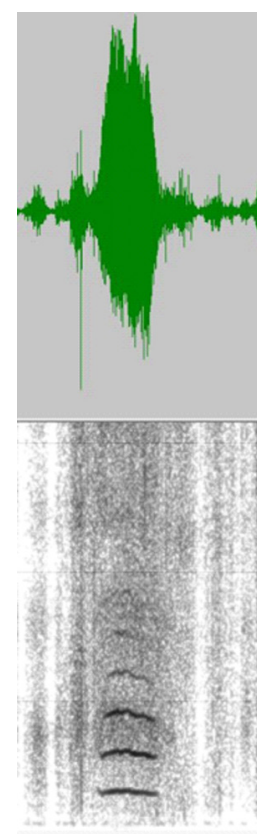

Vocant

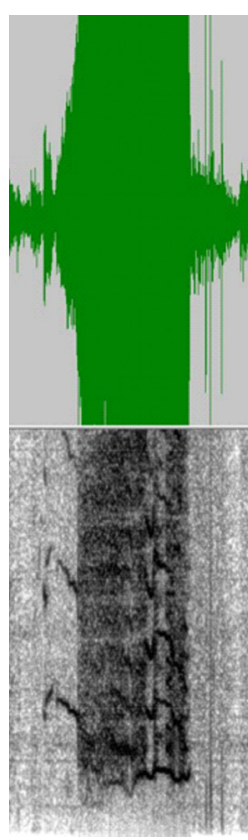

Squeal
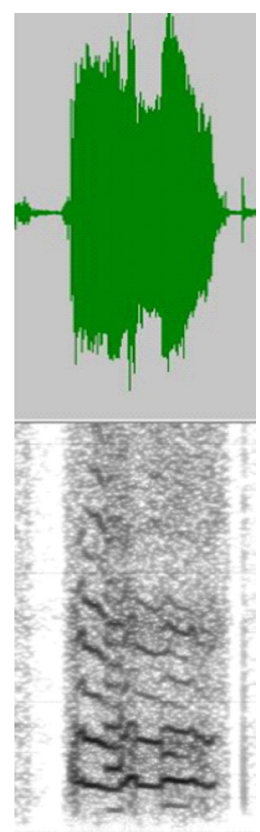

Growl (C)
Figure 1. Examples of three vocal types.

발성 자료를 분석하기 위해서 언어병리학 전공 대학생 3 명, 대학 원생 1 명이 영아의 발성을 듣고 유형을 분류하였다. 분석자들 간의 분류 신뢰도를 위하여 분석자들은 저자들로부터 집중적인 청지각 훈련을 받았다. 훈련에는 열거된 세 가지 원시발성 유형에 대한 정 의와 실제 발성의 예가 포함되었다. 또한 분석자들이 실제로 5 분 길 이의 음성 자료 20 개를 듣고 유형을 분류하는 훈련을 통해 분석자 들 간의 신뢰 상관 계수가. 80 이상에 도달한 후 본 연구를 위한 분 석을 시작하였다.

LENA 녹음기로 녹음된 자료는 상세한 발성 유형 분석을 위해 우선 자동 분석 소프트웨어인 LENA pro에 저장하였다. 12시간 이 상 녹음된 각 아동의 전체 음성 파일에서 무작위로 5 분씩 추출하 여 21 개의 음성파일을 만들어, 한 아동 당 총 105 분 분량의 발성 자 료를 만들었다. 본 연구에 사용된 발성 자료는 총 63 개로 모두 6,615 분의 분량 자료를 분석자들이 듣고 유형을 분류하였다.

암맹 분석을 위해 영아의 이름과 월령 정보를 제거한 후 분석자 들에게 녹음 자료를 듣고 발성 유형을 분류하게 하였다. 분석자는 추출된 각 5 분 분량의 녹음 파일을 들으며 실시간으로 영아의 발성 유형을 분류하였다. 또한 각 파일의 분류를 마치고 나면 각 파일의 언어 환경 정보 수집을 위해서 7 개 문항의 질문을 1-5까지의 Likert 형 척도를 사용하여 답하였다. 예를 들어, 양육자가 영아에게 5 분 동안 어느 정도 직접적으로 말을 하는지, 양육자를 제외한 다른 성 인이나 아동이 영아에게 말을 거는지, 영아가 잠을 자고 있는지 등 
에 관하여 1 (전혀 없음) 부터 5 (전체 세션 또는 거의 가깝게) 중에 서 분석자가 판단하여 설문지의 질문에 답하였다.

분석자들이 영아의 발성을 들으며 실시간으로 유형을 분류하기 위하여 AACT (Action Analysis Coding \& Training; Delgado, Buder, \& Oller, 2010) 분석 소프트웨어를 사용하였다. AACT는 음성 파일의 파형(waveform)과 스펙트로그램(spectrogram)의 정보를 제공하고 제어창을 통해 실시간으로 영아 발성의 유형을 입력할 수 있게 하여 분석자들이 효율적으로 발성을 분류할 수 있다. 선행연 구에 따르면 실시간 분류와 반복 청취 분류 간의 분류 신뢰 상관계 수가 높아(Jhang, Yoo, \& Oller, 2014) 실시간 분류를 통해 본 연구 를 실시하였다. AACT에 대한 보다자세한 정보는 Ha와 Oller (2019) 를 통해확인할 수 있다.

\section{통계분석}

월령에 따른 발성 발달 양상 분석을 위하여 임의로 2 개월씩(A와 $\mathrm{F}$ 집단은 3개월씩) 월령 집단을 구분하여 자료를 분석하였다. 보다 정확한 발성 산출의 비율 측정을 위하여 분석자들의 설문지를 근 거로 영아가 자고 있는 것으로 판단된 녹음 파일은 통계 분석에서 제외하였다. 본 연구를 위해 분석이 완료된 총 1,323 개의 5 분 녹음 파일 중에서 영아가 수면 중인 파일 86개를 제외하여 1,237 개의 5 분 녹음 파일이 통계분석에 사용되었다. 본 연구의 통계 분석을 위 해 Excel (Microsoft 365 version)과 R (version 4.0.3)을 사용하였다. 발성 유형의 산출 비율과 월령에 따른 변화를 알아보기 위하여 paired $t$-test, repeated-measures ANOVA 및 Generalized Estimating Equations (GEE)를 사용하였다. GEE는 Generalized Linear Models (GLM)의 확장된 형태로 정상 분포를 따르지 않는 자료나 종단 연구 자료의 특징인 반복적인 측정 자료를 분석하기에 유용 한 방법으로 임상 연구 등에서 널리 사용되는 통계분석 방법이다 (Liang \& Zeger, 1986).

Table 2. Protophones and cries per minute across age groups

\begin{tabular}{lccccccc}
\hline & $\begin{array}{c}\text { Numbers } \\
\text { of seg- } \\
\text { ments }\end{array}$ & $\begin{array}{c}\text { ProtPer } \\
\text { minute }\end{array}$ & SD & SE & $\begin{array}{c}\text { Cries } \\
\text { per } \\
\text { minute }\end{array}$ & SD & SE \\
\hline $\mathrm{A}(0-2 \mathrm{mo})$ & 146 & 4.17 & 27.03 & 2.24 & .72 & 15.81 & 1.31 \\
$\mathrm{~B}(3-4 \mathrm{mo})$ & 196 & 3.62 & 21.49 & 1.54 & .7 & 13.6 & .97 \\
$\mathrm{C}(5-6 \mathrm{mo})$ & 197 & 3.03 & 19.53 & 1.39 & .26 & 4.94 & .35 \\
$\mathrm{D}(7-8 \mathrm{mo})$ & 236 & 3.07 & 17.83 & 1.16 & .04 & 1.08 & .07 \\
$\mathrm{E}(9-10 \mathrm{mo})$ & 200 & 4.03 & 20.2 & 1.43 & .28 & 8.6 & .61 \\
$\mathrm{~F}(11-13 \mathrm{mo})$ & 262 & 3.62 & 17.61 & 1.09 & .19 & 4.15 & .26 \\
\hline
\end{tabular}

Prot=Protophones; $\mathrm{SD}=$ Standard deviation; $\mathrm{SE}=$ Standard error.

\section{연구결과}

\section{신생아 시기의 원시발성과 울음 산출 비율}

월령별 원시발성 및 울음의 분당 평균 산출량을 Table 2에 제시 하였다. 원시발성 분당 평균 산출량은 월령 집단별로 3.03-4.17개, 울음은 .04-.72개로 신생아 시기부터 원시발성이 산출되었으며 울음 에 비해 원시발성의 산출량이 현저히 높았다 $\left(t_{(1,694)}=-25.3, p<.001\right)$. 한편 전체 월령 집단의 평균 원시발성 분당 산출량은 3.6 개, 울음은 0.3 개였다.

\section{원시발성과 울음의 월령별 산출 비율}

원시발성과 울음의 월령 집단별 산출량 및 발달 양상을 조사하 기 위하여 GEE를 이용하여 분석한 결과, 월령별 원시발성의 산출 량 차이는 통계적으로 유의미하지 않았다. 울음의 경우도 GEE 분 석 결과, 월령별 산출량은 통계적으로 유의미하지 않았다.

종합하면 원시발성은 신생아 시기부터 산출되었으며, 신생아 시 기에 다소 높게 나타났으나 모든 월령에서 비교적 비슷한 산출량을 보였다. 또한 원시발성은 신생아 시기부터 13 개월까지 지속적으로 울음에 비해 현저히 높은 평균 산출량을 보였다. 울음의 경우는 어 린 월령에서 비교적 평균 산출량이 높았고 월령이 증가할 수록 대 체로 감소하는 추세를 보였으나 차이가 통계적으로 유의미한 수준 은 아니었다.

\section{원시발성과 유형에 따른 산출 비율}

Repeated-measures ANOVA 및 Bonferroni 사후 분석 결과, 원 시발성 중 대표적인 세 가지 유형(고성, 중성, 탁성)의 전체 평균 발 성 산출량은 통계적으로 유의미한 차이를 보였다 $\left(F_{(22,472)}=666.54\right.$, $p<0.001)$. 구체적으로는 중성 $(\mathrm{M}=14.13, \mathrm{SD}=3.45)$ 의 산출량이 가

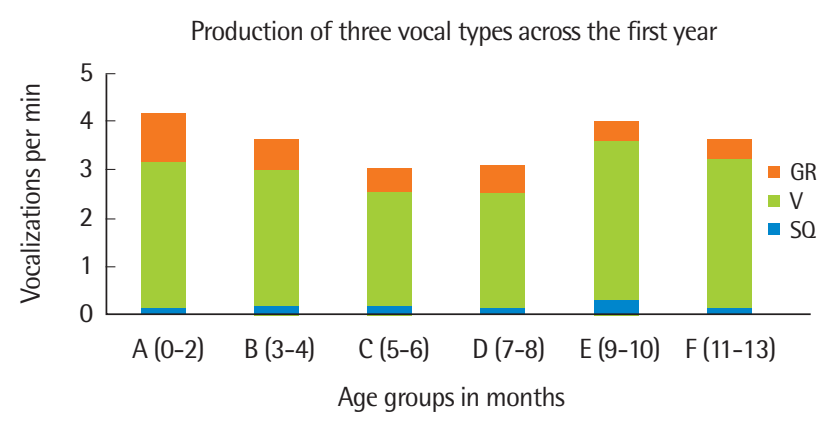

Figure 2. Three types of vocalizations per minute across age groups. Growls, vocants and squeals per minute across the first year of life. Vocants were predominantly produced compared to squeals and growls. $\mathrm{GR}=\mathrm{Growls} ; \mathrm{V}=$ Vocants; $\mathrm{S} Q=$ Squeals. 
장 높았고, 탁성 $(\mathrm{M}=2.81, \mathrm{SD}=1.03)$ 과 고성 $(\mathrm{M}=0.83, \mathrm{SD}=0.44)$ 순으로 산출량이 나타났다. 각 유형별 분당 산출량도 월령에 따라 차이를 보였다(Figure 2). GEE 분석 결과 탁성의 경우 영아의 월령 $(p=.02)$ 이 분석 모델에서 통계적으로 유의미하였다. 구체적으로는 0-2개월 집단의 산출량보다 9-10개월, 11-13개월 집단의 산출량이 통계적으로 유의미하게 적었다. 그러나 중성과 고성의 경우는 월령 집단별 산출량이 통계적으로 유의미하지 않았다. 정리하면, 중성 이 고성과 탁성에 비해 현저히 높은 전체 평균 산출량을 보였으며, 탁성의 경우 부분적으로 월령 집단별로 산출량 차이를 보였으나, 중성과 고성의 경우에는 유의미한 차이가 없었다.

\section{자발적인 원시발성의 산출}

영아가 성인의 언어(직접 혹은 간접적) 자극이 없는 상황에서도 자발적으로 원시발성을 산출하는지를 살펴보았다. 분석자가 작성 한 각 5 분 녹음 파일의 언어 환경 설문지를 근거로 하여 양육자가 영아에게 직접 말을 걸지 않았고, 성인끼리 서로 대화를 하지 않았 던 파일은 전체 파일의 $7 \%$ (84개)였다. 이 파일의 평균 원시발성 산 출량은 $15.25(\mathrm{SD}=2.9)$ 개 였으며, 분당 평균 산출량은 2.89 개, 최대 산출량은 79개 였다. 이는 전체 파일을 대상으로 분석한 결과(분당 평균 산출량: 3.56개)와 통계적으로 유의미한 차이가 없는 쪽에 가 까웠다 $\left(t_{(107)}=1.96, p=.051\right)$. 다시 말하면, 영아에게 언어적 자극이 없는 상황에서 영아가 발성 산출을 멈추는 것이 아니라(성인에 언 어적 자극에 의해서만 발성하는 것이 아니라) 자발적으로 발성을 산출하고 연습한다고 할수 있다.

\section{논의 및 결론}

본 연구에서는 영유아의 말-언어발달에 매우 중요한 원시발성 그 중에서도 발성/음성 조절 연습 및 능력의 발달을 보여주는 세 가 지 하부 유형(중성, 고성, 탁성)과 울음의 산출 비율을 비교하고 산 출 비율을 월령 집단별로 조사하였다. 특히 원시발성이 생후 직후 부터 산출되는지 실제 녹음 자료를 통해 알아보는 것이 본 연구의 중요한 목적 중의 하나였다.

먼저, 원시발성은 생후 직후인 신생아 시기부터(A: 0-2개월) 산출 이 시작되어 생후 1 년 동안 일관적으로 높은 분당 산출량을 보였으 며(분당 평균 산출량: 3.56 개), 울음에 비해 분당 평균 산출량이 현 저히 높았다. 이는 선행연구와 일치하는 결과로 Oller 등(2019)은 0-12개월의 영아가 평균 원시발성 산출량이 분당 4-5개, 울음은 평 균 1 개 미만으로 보고하였다. 같은 연구에서 미숙아의 경우에는 평 균 분당 산출량이 2-3개로 조금 낮아졌지만, 여전히 울음에 비해서
는 현저히 높은 산출량을 보였다. Nathani 등(2006)은 분당 산출량 대신 말소리와 비슷한 발성과 말소리 같지 않은 발성의 산출 비율 을 보고하였는데, 신생아 시기에는 말소리와 비슷한 발성이 전체 발 성의 $65 \%$ 정도를 차지하다 점점 산출 비율이 월령에 따라 증가하 여 16-20개월에는 $94 \%$ 까지 증가하였다. 원시대화와 영아의 원시발 성을 연구한 여러 선행연구에서도 생후 직후부터 원시발성의 출현 을 보고하였다. 예를 들어, Dominguez, Devouche, Apter, \& Gratier (2016)은 생후 2-4일의 영아가 분당 .1-10.4개의 원시발성을 산출 한다고 보고하였다. 선행연구와 본 연구에서 일관적으로 증명된 원 시발성의 조기 출현은 원시발성이 말-언어발달의 전조로서 중요한 역할임을 보여준다. 또한 일부 연구자들의 추측이나 일반인들의 가 정과 달리 울음의 산출량은 생후 초기부터 원시발성에 비해 현저 히 적었다.

더불어 원시발성의 하부 유형별 발달을 분석한 결과, 중성의 경 우는 월령별로 유의미한 차이 없이 비슷하게 높은 산출 비율을 보 였으나, 탁성은 월령 집단별로 일부 월령 집단에서 유의미한 차이 를 보였다. 중성이 가장 높은 산출 비율을 보였다는 것은 영유아의 발성 발달에 있어 중요한 의미를 가진다. Nathani 등(2006)은 모음 의 산출량이 다른 종류의 발성에 비해 현저히 많은 것을 보고하였 다. 청각장애 아동의 경우 모음 발달에 어려움이 있음을 지적하며 모음의 출현과산출량의 증가가 초기 언어발달에 중요한 지표가 될 수 있음을 제안하였다. 본 연구의 경우 중성은 모음뿐만 아니라 자 음이 포함된 음절성 옹알이의 경우에도 발성/음성적인 특성만을 고려하여 유형을 분류하였으므로 Nathani 등(2006)의 연구결과와 직접 비교는 적절하지 않다. 그러나음절성 옹알이가 출현하기 전인 보통 6개월 이전의 경우에는 대부분의 중성에 모음이 포함되었으 므로 본 연구에서도 모음의 높은 산출량을 간접적으로 추론할 수 있다. 또한 본 연구의 분류 유형인 중성은 성인의 일반적인 구어에 서 주로 사용되는 음역대로서 언어발달 및 생활에 기초가 되는 중 성을 완전히 습득하는 것은 영아의 말-언어발달에 있어 중요한 과 제이다. 본 연구에서는 모든 월령 집단에서 다른 두 유형에 비해 중 성의 월등한 산출량이 나타나 영아의 발성 발달에 있어 중성 습득 의 과정과 중요성을 보여주었다.

고성과 탁성의 경우는 중성에 비해 산출량이 모든 월령 집단에 서 현저히 적었지만, 일부 집단의 경우 월령별 차이가 나타났다. 탁 성은 중성 다음으로 산출량이 많았으며, 가장 어린 연령인 0-2개월 집단에서 가장 많이 산출되었고 대체로 월령이 증가할수록 감소하 는 성향을 보였다. Jhang과 Oller (2017)는 0, 1, 2개월 영아 원시발성 의 기능적 유연성에 대해 연구하였는데, 이 연구에서도 가장 어린 연령인 0 개월의 탁성 산출량이 다른 두 연령에 비해 가장 많았다. 
연구의 목적이 달라서 비록 월령별 산출량이 보고되지는 않았지만 Oller 등(2013)에서도 원시발성 유형별 산출량을 보면 3-12개월의 원시발성 중 중성 다음으로 탁성의 발성 산출량이 많았다. 선행연 구과 본 연구에서 모두 일관되게 어린 월령에서 비교적 높은 탁성 의 산출량을 보고하였다. 그러나 이는 실제 영아가 탁성의 발성 산 출이 많았을 가능성과 함께 분석 과정에서의 오류 가능성도 고려 해야 한다. 탁성은 영아가 움직일 때 부수적으로 산출되는 그렁거 림 소리와 특성이 비슷하여 비디오 자료 없이 음성만으로 판단하 는 경우에는 착오가 생길 가능성이 있기 때문이다. 보다 정확한 결 론을 위해서는 비디오 자료와 함께 더 많은 영아를 대상으로 한 후 속연구가 필요하다. 고성의 경우 다른 두 유형에 비해 낮은 산출량 을 보였고, 통계적으로 유의미한 차이는 없었지만 가장 어린 월령 인 0-2개월 집단이 산출량도 가장 적었다. 종합하면 중성을 기준으 로 하여 고성과 탁성이 음도의 높낮이를 탐색하고 연습하는 발성으 로 신생아 시기부터 산출이 관찰되어 생후 일년 간 지속적으로 산 출되었다. 그러나 중성에 비해서는 고성과 탁성의 산출량이 현저히 적다는 것도 발성 발달에 있어 중요한 의미를 가질 수 있다. Sheinkopf, Mundy, Oller와 Steffens (2000)는 자폐 아동의 경우 발달 지연 아 동에 비해 비전형적 발성의 산출이 많다고 보고하고 있는데, 비전 형적 발성의 유형 중 하나가 고성이었다. 아직 더 많은 연구가 필요 한 단계지만 발성 유형에 따른 산출량의 차이가 말-언어발달 지연 이나 발달 장애의 지표로 사용될 수도 있음을 시사한다. 동시에 중 성이 가장 기초가 되고 일상에서 많이 쓰이는 발성으로 산출량 역 시 다른 유형보다 많으며, 고성과 탁성의 경우는 영아가 발성 연습 을 위해 산출하는 것을 고려하더라도 일반적인 발달의 경우에는 산출량이 대체로 적다는 것을 알수 있다.

마지막으로 본 연구에서는 원시발성의 자발성에 대해서도 살펴 보았다. 이를 위해 영아가 언어 환경적으로 성인의 언어 자극이 없 는 상황에서도 원시발성을 산출하는지를 조사하였다. 설문지를 근 거로 하여 양육자가 직접적으로 영아에게 말을 걸지 않았고, 영아 의 주위에서 성인끼리 서로 대화를 하지 않아 영아에게 언어 자극 이 없거나 매우 적었던 파일을 선택하였다. 이러한 환경에서도 영아 는 평균 분당 원시발성을 2.89 개 산출하였다. 이는 모든 파일을 대 상으로 하였을 때의 분당 산출량인 3.56개 보다 적지만 자발성을 나타내기에는 충분한 양이다. 지금까지 많은 연구자 및 일반인들은 성인의 언어자극이 있을 때 영아가 발성을 산출한다고 가정하였다. 그러나 최근 Long 등(2020)의 연구에서 영아의 대부분의 발성이 (75-79\%) 사회적 발성이 아닌(non-socially directed; 음성 놀이, 감 정 표현 등) 자발적 발성(endogenous vocalizations)이었고, 사회적 발성(양육자와의 상호작용 상황)에 비해 현저히 산출률이 높았다.
Oller 등(2019)에서 역시 영아가 혼자 있는 상황에서 분당 평균 원 시발성의 산출률을 3 개로 보고하여 본 연구의 결과와 일치하였다. 이는 원시발성의 가장 큰 특성 중의 하나인 자발적인 발성을 보여 주는 결과이다. 선행연구와 본 연구 모두 영아의 말-언어발달에 있 어 양육자의 언어 자극이 매우 중요하다는 점을 인지하고 있지만, 양육자와 영아 간의 상호작용을 위해서는 먼저 기초가 되는 특성, 즉 내적인 동기로 인한 원시발성의 자발성이 전제가 되어야 한다는 것을 나타낸다 (Moulin-Frier et al., 2014). 양육자의 언어 자극은 영 아의 말-언어발달을 촉진하는 중요한 역할을 하지만 이러한 상호작 용과 영아의 말-언어발달을 가능하게 하는 발달적인 전제 및 선행 단계는 원시발성의 자발성이라 할 수 있다(Oller et al., 2016).

본 연구는 생후 직후부터 일년 동안 울음과 비교할 때 원시발성 의 높은 산출 비율을 보여주었다. 본 연구의 결과대로 신생아 시기 부터 원시발성이 산출되고 원시발성의 산출 비율이 울음의 산출 비율보다 현저히 높게 나타난다는 것은 말-언어발달과 관련한 연구 및 임상 적용에 중요한 의의를 가진다. 이는 원시발성의 기능이 울 음과는 매우 구별된다는 것을 나타내며, 영어권 선행연구와의 일치 된 결과를 통해 발성/음성 발달의 보편성에 대해서도 경험적인 증 거가 될 수 있다. 더불어 본 연구의 결과를 바탕으로 임상적으로 생 후 초기부터 양육자에게 원시대화를 유도하도록 권고하여 영아의 말-언어발달을 위한 적절한 언어 자극을 영아에게 조기부터 제공 할수 있을 것이다.

\section{REFERENCES}

Belardi, K., Watson, L. R., Faldowski, R. A., Hazlett, H., Crais, E., Baranek, G. T., ... \& Oller, D. K. (2017). A retrospective video analysis of canonical babbling and volubility in infants with Fragile X Syndrome at 9-12 months of age. Journal of Autism and Developmental Disorders, 47(4), 1193-1206.

Brainard, M. S., \& Doupe, A. J. (2000). Auditory feedback in learning and maintenance of vocal behaviour. Nature Reviews Neuroscience, 1(1), 31-40. Buder, E. H., Chorna, L. B., Oller, D. K., \& Robinson, R. B. (2008). Vibratory regime classification of infant phonation. Journal of Voice, 22(5), 553-564.

Buder, E. H., Jarmulowicz, L., \& Oller, D. K. (2013). Acquisition of the English voicing contrast by native Spanish-speaking children: phonological development in voice onset times. In B. Peter \& A. A. N. MacLeod (Eds.), Comprehensive perspectives on child speech development and disorders: pathways from linguistic theory to clinical practice (pp.326-342). Hauppage, NY: Nova Science Publishers, Inc.

Delgado, R. E., Buder, E. H., \& Oller, D. K. (2010). Action analysis coding and 
training (AACT). Miami, FL: Intelligent Hearing Systems.

Dominguez, S., Devouche, E., Apter, G., \& Gratier, M. (2016). The roots of turn-taking in the neonatal period. Infant and Child Development, 25(3), 240-255.

Fagan, M. K., \& Doveikis, K. N. (2017). Ordinary interactions challenge proposals that maternal verbal responses shape infant vocal development. Journal of Speech, Language, and Hearing Research, 60(10), 2819-2827.

Ferguson, C. A., Macken, M. A., \& Nelson, K. E. (1983). The role of play in phonological development. Hillsdale, NJ: Lawrence Erlbaum.

Fogel, A., Toda, S., \& Kawai, M. (1988). Mother-infant face-to-face interaction in Japan and the United States: a laboratory comparison using 3-monthold infants. Developmental Psychology, 24(3), 398-406.

Ha, S., \& Oller, D. K. (2019). Canonical babbling in Korean-acquiring infants at 4-9 months of age. Communication Sciences \& Disorders, 24(1), 1-8.

Ha, S., Seol, A., \& Pae, S. (2014). Vocal development of typically developing infants. Phonetics and Speech Sciences, 6(4), 161-169.

Hoff, E. (2009). Language development at an early age: learning mechanisms and outcomes from birth to five years. In R. E. Tremblay, M. Boivin, R. D. V. Peters, \& S. Rvachew (Eds.), Encyclopedia of early childhood development. [Epub]. http://www.child-encyclopedia.com/language development-andliteracy/according-experts/language-development-early-age-learning.

Hollien, H., Girard, G. T., \& Coleman, R. F. (1977). Vocal fold vibratory patterns of pulse register phonation. Folia Phoniatrica et Logopaedica, 29(3), 200-205.

Jang, H., \& Ha, S. (2019). Protophone development at 4-6 months and 7-9 months of Age. Communication Sciences \& Disorders, 24(3), 707-714.

Jang, H., \& Ha, S. (2020). Canonical babbling development in Korean-acquiring Infants. Communication Sciences \& Disorders, 25(1), 104-112.

Jhang, Y., \& Oller, D. K. (2017). Emergence of functional flexibility in infant vocalizations of the first 3 months. Frontiers in Psychology, 8, 1-11.

Jhang, Y., Yoo, H., \& Oller, D. K. (2014). Canonical babbling judged in real-time as a screening tool. Paper presented at the American Speech-LanguageHearing Association Convention, Orlando, Florida.

Kärtner, J., Keller, H., \& Yovsi, R. D. (2010). Mother-infant interaction during the first 3 months: the emergence of culture-specific contingency patterns. Child Development, 81(2), 540-554.

Keller, H., Kärtner, J., Borke, J., Yovsi, R., \& Kleis, A. (2005). Parenting styles and the development of the categorical self: a longitudinal study on mirror self-recognition in Cameroonian Nso and German families. International Journal of Behavioral Development, 29(6), 496-504.
Kim, J., Yoon, J., Park, H., Park, K., \& Lee, J. (2017). The development of Korean infant vocal and articulatory development list. Audiology and Speech Research, 13(2), 141-160.

Koopmans-van Beinum, F. J., \& van der Stelt, J. M. (1986). Early stages in the development of speech movements. In B. Lindblom \& R. Zetterström (Eds.), Precursors of early speech (pp. 37-50). London, United Kingdom: Macmillan.

Lang, S., Bartl-Pokorny, K. D., Pokorny, F. B., Garrido, D., Mani, N., Fox-Boyer, A. V., ... \& Marschik, P. B. (2019). Canonical babbling: a marker for earlier identification of late detected developmental disorders?. Current Developmental Disorders Reports, 6(3), 111-118.

Lester, B. M., \& Boukydis, C. F. Z. (1992). No language but a cry. In H. Papoušek, U. Jürgens, \& M. Papoušek (Eds.), Nonverbal vocal communication (pp 145-173). New York, NY: Cambridge University Press.

Liang, K. Y., \& Zeger, S. L. (1986). Longitudinal data analysis using generalized linear models. Biometrika, 73(1), 13-22.

Locke, J. L. (1989). Babbling and early speech: continuity and individual differences. First Language, 9(6), 191-205.

Locke, J. L. (2006). Parental selection of vocal behavior. Human Nature, 17(2), 155-168.

Locke, J. L. (2008). Lipsmacking and babbling: syllables, sociality, and survival. In B. L. Davis, \& K. Zajdo (Eds.), The syllable in speech production (pp. 111-129). New York: Erlbaum.

Locke, J. L. (2017). Emancipation of the voice: vocal complexity as a fitness indicator. Psychonomic Bulletin \& Review, 24(1), 232-237.

Locke, J. L., \& Bogin, B. (2006). Language and life history: a new perspective on the development and evolution of human language. Behavioral and Brain Sciences, 29(3), 259-325.

Long, H. L., Bowman, D. D., Yoo, H., Burkhardt-Reed, M. M., Bene, E. R., Oller, D. K. (2020). Social and endogenous infant vocalizations. PLoS One, 15(8), e0224956.

Lynch, M. P., Oller, D. K., Steffens, M. L., \& Buder, E. H. (1995). Phrasing in prelinguistic vocalizations. Developmental Psychobiology, 28(1), 3-25.

Moulin-Frier, C., Nguyen, S. M., \& Oudeyer, P. Y. (2014). Self-organization of early vocal development in infants and machines: the role of intrinsic motivation. Frontiers in Psychology, 4, 1-20.

Nathani, S., Ertmer, D. J., \& Stark, R. E. (2006). Assessing vocal development in infants and toddlers. Clinical Linguistics \& Phonetics, 20(5), 351-369.

National Institute of Korean Language. (2008). National Institute of Korean Language Standard Dictionary. Retrieved from https://stdict.korean.go.kr/ 
main/main.do.

Nyman, A., \& Lohmander, A. (2018). Babbling in children with neurodevelopmental disability and validity of a simplified way of measuring canonical babbling ratio. Clinical Linguistics \& Phonetics, 32(2), 114-127.

Oller, D. K. (2000). The emergence of the capacity for speech. Mahwah, NJ: Erlbaum.

Oller, D. K., Buder, E. H., Ramsdell, H. L., Warlaumont, A. S., Chorna, L., \& Bakeman, R. (2013). Functional flexibility of infant vocalization and the emergence of language. Proceedings of the National Academy of Sciences, 110(16), 6318-6323.

Oller, D. K., Caskey, M., Yoo, H., Bene, E. R., Jhang, Y., Lee, C. C., ... \& Vohr, B. (2019). Preterm and full term infant vocalization and the origin of language. Scientific Reports, 9(1), 1-10.

Oller, D. K., \& Eilers, R. E. (1988). The role of audition in infant babbling. Child Development, 59(2), 441-449.

Oller, D. K., Eilers, R. E., Neal, A. R., \& Cobo-Lewis, A. B. (1998). Late onset canonical babbling: a possible early marker of abnormal development. American Journal on Mental Retardation, 103(3), 249-263.

Oller, D. K., Griebel, U., \& Warlaumont, A. S. (2016). Vocal development as a guide to modeling the evolution of language. Topics in Cognitive Science, $8(2), 382-392$.

Oller, D. K., Niyogi, P., Gray, S., Richards, J. A., Gilkerson, J., Xu, D., ... \& Warren, S. F. (2010). Automated vocal analysis of naturalistic recordings from children with autism, language delay, and typical development. Proceedings of the National Academy of Sciences, 107(30), 13354-13359.

Oller, D. K., Vohr, B. R., Caskey, M., Yoo, H., Bene, E. R., Jhang, Y., ... Warlaumont, A. Griebel, U., and Buder, E. H. (2014). Infant vocalization and birdsong: an infrastructural view. In Society for Neuroscience satellite meeting: Birdsong4: Rhythms and Clues from Neurons to Behavior. Washington, DC.

Pae, J. Y., \& Ko, D. H. (2010). Features of Korean infants' vocalizations according to the stages models: focused on 1 to 18 months. Phonetics and Speech Sciences, 2(2), 27-36.

Pae, S., \& Kwak, K. C. (2011). Korean MacArthur-Bates communicative development inventories (KMB CDI). Seoul: Mindpress.

Papoušek, M. (1995). Origins of reciprocity and mutuality in prelinguistic parent-infant dialogues. In I. Markova, C. F. Graumann, \& K. Foppa (Eds.), Mutualities in dialogue (pp.58-81). Cambridge, UK: Cambridge University Press.

Papoušek, H., \& Papoušek, M. (2002). Intuitive parenting. In M. H. Bornstein
(Ed.), Handbook of parenting volume 2 biology and ecology of parenting (pp.183-203). Mahwah, NJ: Lawrence Erlbaum Associates, Inc.

Patten, E., Belardi, K., Baranek, G. T., Watson, L. R., Labban, J. D., \& Oller, D. K. (2014). Vocal patterns in infants with autism spectrum disorder: canonical babbling status and vocalization frequency. Journal of Autism and Developmental Disorders, 44(10), 2413-2428.

Sheinkopf, S. J., Mundy, P., Oller, D. K., \& Steffens, M. (2000). Vocal atypicalities of preverbal autistic children. Journal of Autism and Developmental Disorders, 30(4), 345-354.

Stark, R. E. (1980). Stage of speech development in the first year of life. In G. H. Yeni-Komshian, J. F. Kavanagh, \& C. A. Ferguson (Eds.), Child phonology (pp. 73-92). New York, NY: Academic Press.

Stark, R. E., Bernstein, L. E., \& Demorest, M. E. (1993). Vocal communication in the first 18 months of life. Journal of Speech, Language, and Hearing Research, 36(3), 548-558.

Titze, I. R. (2008). Nonlinear source-filter coupling in phonation: theory. The Journal of the Acoustical Society of America, 123(4), 1902-1915.

Törölä, H., Lehtihalmes, M., Heikkinen, H., Olsén, P., \& Yliherva, A. (2012). Early vocalization of preterm infants with extremely low birth weight (ELBW), part II: from canonical babbling up to the appearance of the first word. Clinical Linguistics \& Phonetics, 26(4), 345-356.

Trevarthen, C. (1977). Descriptive analyses of infant communicative behavior. In H. R. Schaffer (Ed.), Studies in mother-infant interaction (pp. 227-270). London, UK: Academic Press.

Tronick, E., Als, H., \& Brazelton, T. B. (1980). Monadic phases: a structural descriptive analysis of infant-mother face to face interaction. Merrill-Palmer Quarterly, 26(1), 3-24.

Vihman, M. M., Macken, M. A., Miller, R., Simmons, H., \& Miller, J. (1985). From babbling to speech: a re-assessment of the continuity issue. Language, 61(2), 397-445.

Warlaumont, A. S., \& Finnegan, M. K. (2016). Learning to produce syllabic speech sounds via reward-modulated neural plasticity. PloS ONE, 11(1), e0145096.

Wasz-Hockert, O., Lind, J., Vuorenkoski, V., Partanen, T. \& Valanne, E. (1968). The infant cry: a spectographic and auditory analysis. Climes in Developmental Medicine, 2, 9-42.

Wasz-Höckert, O., Michelsson, K., \& Lind, J. (1985). Twenty-five years of Scandinavian cry research. In C. F. Boukydis \& B. M. Lester (Eds.), Infant crying (pp. 83-104). Boston, MA: Springer.

Wermke, K., Leising, D., \& Stellzig-Eisenhauer, A. (2007). Relation of melody 
complexity in infants' cries to language outcome in the second year of life: a longitudinal study. Clinical Linguistics \& Phonetics, 21(11-12), 961-973.

Whitehurst, G. J., Smith, M., Fischel, J. E., Arnold, D. S., \& Lonigan, C. J. (1991). The continuity of babble and speech in children with specific expressive language delay. Journal of Speech, Language, and Hearing Research, 34(5), 1121-1129.

Xu, D., Yapanel, U., Gray, S., Gilkerson, J., Richards, J., \& Hansen, J. (2008). Signal processing for young child speech language development. Paper presented at the 1st workshop on child, computer and interaction, Chania, Crete, Greece. Retrieved from www.lenafoundation.org/DownloadFile.
aspx/pdf/SignalProcessing_ChildSpeech.

Yoo, H., Bowman, D. A., \& Oller, D. K. (2018). The origin of protoconversation: an examination of caregiver responses to cry and speech-like vocalizations. Frontiers in Psychology, 9, 1-15.

Yoo, H., Buder, E. H., Bowman, D. D., Bidelman, G. M., \& Oller, D. K. (2019). Acoustic correlates and adult perceptions of distress in infant speech-like vocalizations and cries. Frontiers in Psychology, 10, 1-18.

Zeifman, D. M. (2001). An ethological analysis of human infant crying: answering Tinbergen's four questions. Developmental Psychobiology, 39(4), 265-285. 


\section{국문초록}

\section{한국 영아의 초기 원시발성 산출과 발성 발달}

류현주 ${ }^{1} \cdot$ D. Kimbrough Oller $^{2,3} \cdot$ 하승희 ${ }^{4}$

'University of Alabama, ${ }^{2}$ University of Memphis, ${ }^{3}$ Konrad Lorenz Institute for Evolution and Cognition Research, ${ }^{4}$ 한림대학교 언어청각학부, 한림청각언어연구소

배경 및 목적: 영아의 원시발성(protophones) 발달은 말-언어발달의 중요한 기초가 된다. 원시발성 중에서도 발성 조절(phonatory control) 발달과 연관되는 중성(vocant), 고성(squeal), 탁성(growl)의 발달은 조음 및 발성 발달에 중요한 선결과제이다. 더욱이 원시발성이 신생아 시기에도 산출되는지를 조사하는 것은 말-언어발달 연구 및 임상을 위해 중요한 의의를 갖는다. 본 연구의 목적은 (1) 원시발성 의 신생아 시기 산출 여부, (2) 생후 일년 동안의 원시발성과 울음의 산출량 및 발달, (3) 원시발성 유형의 월령별 발달 추이를 조사하는 데 있다. 더불어 원시발성의 자발성을 알아보기 위하여 양육자의 언어 자극이 없는 상황에서 원시발성의 산출 비율을 조사하였다. 방 법: 일반 영아 16명을 대상으로 LENA (Language ENvironment Analysis system) 녹음기를 이용하여 종단 연구의 일환으로 발성 자료 를 수집하였다. 영아 생후 일년 동안의 원시발성 발달 양상을 알아보기 위하여 각 발성 유형을 청지각적 기준에 따라 분류하고 평균 산 출량 및 분당 평균 산출량을 분석하였다. 통계 분석을 위하여 Generalized Estimating Equations (GEE), $t$-test와 ANOVA가 사용되었 다. 결과: 연구 결과, 신생아 시기에도 울음이 아니라, 원시발성이 현저히 산출 비율이 높았으며, 양육자의 언어 자극이 없는 환경에서도 원시발성이 자발적으로 산출되었다. 논의 및 결론: 신생아 시기의 자발적인 원시발성의 조기 출현과 말-언어발달과의 연관성에 대해 논 의하였다.

핵심어: 원시발성, LENA, 신생아, 영아, 울음

\section{참고문헌}

국립국어원 (2008). 국립국어원 표준 대사전. 서울: 국립국어원.

김진숙, 윤지은, 박혜진, 박경영, 이지현 (2017). 국내 영아의 발성 및 조음발달 목록 개발. 한국청각언어재활학회, 13(2), 141-160.

배소영, 곽금주 (2011). 한국판 맥아더-베이츠 의사소통발달평가(K M-B CDI). 서울: 마인드프레스.

배재연, 고도흥 (2010). 음성발달 모델에 따른 1-18개월 영유아의 음성특징. 말소리와음성과학, 2(2), 27-36.

장현성, 하승희 (2019). 4-6개월과 7-9개월 영아의 발성 발달. Communication Sciences \& Disorders, 24(3), 707-714.

장현성, 하승희 (2020). 한국 아동의 음절성 옹알이 발달. Communication Sciences \& Disorders, 25(1), 104-112.

하승희, 설아영, 배소영 (2014). 일반 영유아의 초기 발성 발달 연구. 말소리와음성과학, 6(4), 161-169.

하승희, D. Kimbrough Oller (2019). 4-9개월 한국 아동의 음절성 옹알이. Communication Sciences \& Disorders, 24(1), 1-8.

\section{ORCID}

류현주(제1저자, 교수 https://orcid.org/0000-0002-1878-0768); D. Kimbrough Oller (공동저자, 교수 https://orcid.org/0000-0001-5527-5982); 하승희(교신저자, 교수 https://orcid.org/0000-0003-2133-3720) 